\title{
Current Microbiology of Surgical Site Infections in Patients with Cancer: A Retrospective Review
}

\author{
Kenneth V. I. Rolston • Lior Nesher · Jeffrey T. Tarrand
}

To view enhanced content go to www.infectiousdiseases-open.com Received: September 11, 2014 / Published online: November 18, 2014

(c) The Author(s) 2014. This article is published with open access at Springerlink.com

\section{ABSTRACT}

Background: Patients with solid tumors frequently undergo surgical procedures and develop procedure-related infections. We sought to describe the current microbiologic spectrum of infections at various sites following common surgical procedures.

Methods: This was a retrospective review of microbiologic data between January 2011 and February 2012. The sites studied were those associated with breast cancer surgery, thoracotomy, craniotomy, percutaneous endoscopic gastrostomy (PEG) tube insertion,

Electronic supplementary material The online version of this article (doi:10.1007/s40121-014-0048-4) contains supplementary material, which is available to authorized users.

K. V. I. Rolston $(\bowtie) \cdot$ L. Nesher

Department of Infectious Diseases, Infection Control and Employee Health, Unit 1460, The University of Texas MD Anderson Cancer Center, 1515 Holcombe Boulevard, Houston, TX, USA e-mail: krolston@mdanderson.org

J. T. Tarrand

Department of Laboratory Medicine, Infection Control and Employee Health, Unit 1460, The University of Texas MD Anderson Cancer Center, 1515 Holcombe Boulevard, Houston, TX, USA and abdominal/pelvic surgery. Only patients with solid tumors were included.

Results: A total of 368 surgical site infections (SSIs) were identified (68 breast cancer related; 91 thoracotomy related; 45 craniotomy related; 75 PEG-tube insertion related; and 89 abdominal/pelvic surgery related). Of these, $58 \%$ were monomicrobial and $42 \%$ were polymicrobial. Overall, $85 \%$ of the 215 monomicrobial infections were caused by Gram-positive organisms and 13\% by Gramnegative bacilli (GNB). Staphylococcus aureus was the predominant pathogen in monomicrobial infections (150 of $215,70 \%)$. Sixty $(40 \%)$ of these staphylococcal isolates were methicillin resistant (MRSA), and 65\% had a vancomycin minimal inhibitory concentration (MIC) $\geq 1.0 \mu \mathrm{g} / \mathrm{ml}$. Pseudomonas aeruginosa was the predominant GNB pathogen (19 of 27, 70\%). Staphylococci were also the predominant pathogens in polymicrobial infections, while $P$. aeruginosa and Escherichia coli were the predominant GNB. Overall, 35\% of isolates from polymicrobial infections were GNB. Cephalosporins (e.g., cefazolin) or amoxicillin/ clavulanate was used most often for surgical prophylaxis, and $47 \%$ of organisms from 
monomicrobial infections (MRSA, $P$. aeruginosa) were resistant to them. A similar resistance pattern was observed in polymicrobial infections.

Conclusion: Staphylococcus species were isolated most often from the sites studied. Polymicrobial infections (42\%) and GNB monomicrobial infections (13\%) were relatively frequent causes of SSIs. Many of these infections were caused by organisms that are resistant to agents commonly used for surgical prophylaxis. Additionally, $65 \%$ of staphylococcal isolates had a vancomycin MIC $\geq 1.0 \mu \mathrm{g} / \mathrm{ml}$, suggesting the need for alternative therapeutic agents.

Keywords: Cancer; Gram-negative bacteria; Gram-positive bacteria; Hematologic malignancies; Surgical site infections

\section{INTRODUCTION}

Patients with cancer develop infections frequently, both as a result of the underlying malignancy, and its treatment [1]. Whereas infections in patients with hematologic malignancies and in recipients of hematopoietic stem cell transplantation have been well studied, data on infections in patients with solid tumors who are not neutropenic are scarce [2, 3]. Our institution has been designated a Comprehensive Cancer Center by the National Cancer Institute, and cares exclusively for patients with cancer. As part of our infection control and antimicrobial stewardship initiatives, we conduct periodic surveillance studies to determine the most current epidemiology/microbiology of infections in our patients [4]. These surveys help us determine the most appropriate antimicrobial agents for prophylaxis, empiric therapy, and targeted therapy for various patient subgroups at our institution [5].
Specific recommendations are included in institutional guidelines and pathways, which are updated periodically.

In contrast to patients with hematologic malignancies, patients with solid tumors frequently undergo various diagnostic and therapeutic surgical procedures, and surgical site infections (SSIs) are among the most common infections seen in such patients [6]. Consequently, peri-operative antimicrobial prophylaxis is administered to the majority of patients undergoing these procedures. Many of the agents (e.g., first- or second-generation cephalosporins) commonly used for prophylaxis were selected for this indication several decades ago, and are probably outdated due to recent epidemiologic changes and alterations in susceptibility/resistance patterns globally [7-10]. Additionally, if a postsurgical infection develops, patients are often given empiric antimicrobial therapy designed to provide coverage against anticipated pathogens, prior to culture results being available. These empiric regimens are adjusted once culture results become available. We recently conducted a survey of the current microbiology of infections associated with common surgical procedures performed at our institution. This information is useful in determining whether our guidelines for prophylaxis and empiric therapy are adequate or need updating. Our findings form the basis of this report. We did not look at treatment and outcomes of these patients, since this was purely a microbiologic survey, and no specific treatment algorithms were being evaluated.

\section{METHODS}

At our institution, all microbiological samples from clinical sources are submitted to and processed by a central microbiology 
laboratory. We conducted a retrospective review of the computerized records of the laboratory between January 2011 and February 2012 to identify episodes of infection associated with (1) breast cancer surgery, (2) thoracic surgery, (3) craniotomy for brain tumor resection, (4) percutaneous endoscopic gastrostomy (PEG) tube insertion, and (5) abdominal/pelvic surgery. These were chosen because they are among the most common procedures performed at our institution. Only patients with solid tumors were studied and only one episode of infection per patient was included in this survey to avoid duplication. Microbial identifications were performed using established criteria [11]. Enterobacteriaceae and most facultative anaerobes were identified using VITEK 1 system (Bio Merieux, Marcy L'Etoile, France). For organisms with questionable identification, $16 \mathrm{~s}$ ribosomal sequencing was performed [12]. Susceptibility testing was performed using the VITEX 1 system using GPS card 119 and GNS card 132 and 134, or E-test method for non-fermenters, fastidious organisms, and the enterococci (AB Biodisk, Solna, Sweden).

Interpretive Standards for Susceptibilities were derived from CLSI, M1 00-518, M7-A 7, and M2-A 10 documents [13]. Our laboratory reports all isolated organisms and does not make specific recommendations regarding their clinical importance, although general notes indicating whether organisms are likely to be colonizers or contaminants are included. We do not routinely perform susceptibility studies on all organisms isolated from polymicrobial infections unless specifically requested by the treating team. Consequently, susceptibility data were not available for some isolates from polymicrobial infections. Our laboratory also does not routinely perform susceptibility testing on common skin colonizers such as coagulase-negative staphylococci and Corynebacterium species unless they are isolated from concomitant blood culture specimens.

All procedures followed were in accordance with the ethical standards of the responsible committee on human experimentation (institutional and national) and with the Helsinki Declaration of 1975 , as revised in 2000 and 2008. Prior to conducting this survey we obtained approval from our Institutional Review Board.

\section{RESULTS}

\section{Patient Characteristics}

During the study period we identified 368 patients with SSIs. Of these, 143 (39\%) were men and 225 (61\%) were women. The age range of the study patients was 17-81 years. The most common underlying tumors were breast cancer (68 patients, 18\%), lung cancer (62 patients, $17 \%)$, head and neck tumors $(61,17 \%)$, brain tumors (45 patients, $12 \%$ ), and ovarian cancers (34 patients, 9\%). Since this was a microbiological survey, it was not possible to determine the exact number of patients who received peri-operative antimicrobial prophylaxis for the surgical procedures they underwent. However, upon review of institutional antimicrobial prophylaxis guidelines/pathways for the procedures studied, the agents used most often were early cephalosporins (cefazolin, cefotetan, and cefoxitin) and amoxicillin/clavulanate. The microbiological details of these SSIs are presented below. 


\section{Infections Associated with Breast Cancer Surgery}

A total of 68 cases of SSIs following breast cancer surgery were identified (Table 1 ). Of these, 41 episodes (60.3\%) were monomicrobial. Methicillin-susceptible Staphylococcus aureus (MSSA) accounted for 18 (43.9\%) of these episodes, followed by methicillin-resistant Staphylococcus aureus (MRSA) with 9 episodes (22.0\%). Other isolated organisms included coagulase-negative staphylococci not routinely identified to species level, but primarily Staphylococcus epidermidis), betahemolytic Streptococcus species (Groups A and B), and Pseudomonas aeruginosa. Twenty-seven of the 68 episodes (39.7\%) were polymicrobial. Staphylococcus species were isolated from all of these episodes including MSSA from 15 episodes (55.6\%), and MRSA from 12 episodes (44.4\%). Other organisms isolated included coagulasenegative staphylococci, Corynebacterium species, beta-hemolytic Streptococcus species (Groups A, B, and C), Enterococcus species, Escherichia coli, Citrobacter species, Klebsiella species, Enterobacter species, Proteus mirabilis and $P$. aeruginosa (Table 1).

\section{Infections Associated with Thoracic Surgery}

Ninety-one SSIs were identified in patients undergoing thoracic surgery. Of these, 58 (63.7\%) were monomicrobial and 33 (36.3\%) were polymicrobial. MSSA was isolated most often (43.1\%) from patients with monomicrobial infections, followed by MRSA $(27.6 \%)$ and beta-hemolytic streptococci (Groups A, B, and G). Other organisms isolated included coagulase-negative staphylococci, $P$. aeruginosa, and E. coli. MRSA was isolated from $60.6 \%$ of episodes of polymicrobial SSIs following thoracic surgery, and MSSA was isolated from $48.5 \%$ of these episodes. Other organisms commonly isolated were betahemolytic Streptococcus species, E. coli, other Enterobacteriaceae, and P. aeruginosa (Table 2).

\section{PEG-tube Insertion Site Infections}

A total of 75 episodes of PEG-tube insertion SSIs were identified during the study period (Table 3). Of these, 39 episodes (52.0\%) were monomicrobial. Organisms most commonly isolated were MSSA (28.2\%), MRSA (20.5\%), $P$. aeruginosa (17.9\%), Streptococcus species and Candida species $(10.3 \%$ each). Thirty-six episodes (48.0\%) were polymicrobial. Staphylococci were isolated from 33 (91.7\%) of these episodes with MSSA being isolated from 21 (58.3\%) and MRSA from 12 (33.3\%). Other common pathogens included $P$. aeruginosa (17 episodes, 47.2\%), E. coli (13 episodes, 36.1\%), other Enterobacteriaceae (16 episodes, 44.4\%), and Streptococcus species (7 episodes, 19.4\%). Candida species were isolated from 18 episodes but the clinical significance of these isolates was unclear.

\section{Craniotomy Site Infections}

A total of 45 craniotomy site infections were identified (Table 4). Of these, 28 (62.2\%) were monomicrobial and $17 \quad(37.8 \%)$ were polymicrobial. The most commonly isolated organisms from monomicrobial infections were MSSA (53.6\%), MRSA (32.1\%), and various Gram-negative rods (14.3\%). The most commonly isolated organisms from polymicrobial infections were MSSA (11 episodes, 64.7\%), MRSA (7 episodes, $41.2 \%$ ), and $P$. aeruginosa (5 episodes, 29.4\%). 
Table 1 Microbiologic details of surgical site infections following breast cancer surgery

\begin{tabular}{|c|c|c|}
\hline $\begin{array}{l}\text { Types of } \\
\text { infection, } \\
n=68\end{array}$ & Organisms & $N(\%)$ \\
\hline \multirow[t]{6}{*}{ Monomicrobial } & Total & $41(60.3)$ \\
\hline & $\begin{array}{l}\text { Staphylococcus aureus } \\
\text { (methicillin susceptible) }\end{array}$ & $18(43.9)$ \\
\hline & $\begin{array}{l}\text { Staphylococcus aureus } \\
\text { (methicillin resistant) }\end{array}$ & $9(22.0)$ \\
\hline & $\begin{array}{l}\text { Coagulase-negative } \\
\text { staphylococci }\end{array}$ & $4(9.8)$ \\
\hline & Streptococcus species & $8(19.5)$ \\
\hline & Pseudomonas aeruginosa & $2(4.9)$ \\
\hline \multirow[t]{13}{*}{ Polymicrobial } & Total & $27(39.7)$ \\
\hline & $\begin{array}{l}\text { Staphylococcus aureus } \\
\text { (methicillin susceptible) }\end{array}$ & $15(55.6)$ \\
\hline & $\begin{array}{l}\text { Staphylococcus aureus } \\
\text { (methicillin resistant) }\end{array}$ & $12(44.4)$ \\
\hline & Klebsiella species & $6(22.2)$ \\
\hline & Corynebacterium species & $2(7.4)$ \\
\hline & Streptococcus species & $8(29.6)$ \\
\hline & Enterococcus species & $2(7.4)$ \\
\hline & Escherichia coli & $9(33.3)$ \\
\hline & Proteus mirabilis & $5(18.5)$ \\
\hline & Enterobacter species & $2(7.4)$ \\
\hline & Citrobacter species & $2(7.4)$ \\
\hline & Pseudomonas aeruginosa & $8(29.6)$ \\
\hline & $\begin{array}{l}\text { Coagulase-negative } \\
\text { staphylococci }\end{array}$ & $4(14.8)$ \\
\hline
\end{tabular}

\section{Abdominal and Pelvic Wound Infections}

A total of 89 episodes of infection associated with abdominal/pelvic surgery were identified (Table 5). Of these, $49 \quad(55.1 \%)$ were monomicrobial and 40 (44.9\%) were polymicrobial. The most commonly isolated
Table 2 Microbiologic details of surgical site infections following thoracotomy

\begin{tabular}{|c|c|c|}
\hline $\begin{array}{l}\text { Types of } \\
\text { infection, } \\
n=91\end{array}$ & Organisms & $N(\%)$ \\
\hline \multirow[t]{7}{*}{ Monomicrobial } & Total & $58(63.7)$ \\
\hline & $\begin{array}{l}\text { Staphylococcus aureus } \\
\text { (methicillin susceptible) }\end{array}$ & $25(43.1)$ \\
\hline & $\begin{array}{l}\text { Staphylococcus aureus } \\
\text { (methicillin resistant) }\end{array}$ & $16(27.6)$ \\
\hline & $\begin{array}{l}\text { Coagulase-negative } \\
\text { staphylococci }\end{array}$ & $4(6.9)$ \\
\hline & Streptococcus species & $9(15.5)$ \\
\hline & Pseudomonas aeruginosa & $3(5.2)$ \\
\hline & Escherichia coli & $1(1.7)$ \\
\hline \multirow[t]{10}{*}{ Polymicrobial } & Total & $33(36.3)$ \\
\hline & $\begin{array}{l}\text { Staphylococcus aureus } \\
\text { (methicillin susceptible) }\end{array}$ & $16(48.5)$ \\
\hline & $\begin{array}{l}\text { Staphylococcus aureus } \\
\text { (methicillin resistant) }\end{array}$ & $20(60.6)$ \\
\hline & $\begin{array}{l}\text { Coagulase-negative } \\
\text { staphylococci }\end{array}$ & $6(18.2)$ \\
\hline & Corynebacterium species & $2(6.1)$ \\
\hline & Bacillus species & $2(6.1)$ \\
\hline & Streptococcus species & $11(33.3)$ \\
\hline & Escherichia coli & $8(24.2)$ \\
\hline & Pseudomonas aeruginosa & $7(21.2)$ \\
\hline & Other Enterobacteriaceae & $11(33.3)$ \\
\hline
\end{tabular}

organisms from monomicrobial infections were MSSA (42.9\%), MRSA (36.7\%), $P$. aeruginosa (10.2\%), and other enteric Gramnegative bacteria. The most commonly isolated organism from polymicrobial infections were MSSA (26 episodes, 65.0\%), MRSA (19 episodes, $47.5 \%$ ), P. aeruginosa (9 episodes, $22.5 \%$ ), other enteric Gram-negative bacteria, Candida species, and Enterococcus species. 
Table 3 Microbiologic details of PEG-tube insertion site infections in cancer patients

\begin{tabular}{|c|c|c|}
\hline $\begin{array}{l}\text { Types of } \\
\text { infection, } \\
n=75\end{array}$ & Organisms & $N(\%)$ \\
\hline \multirow[t]{8}{*}{ Monomicrobial } & Total & $39(52.0)$ \\
\hline & $\begin{array}{l}\text { Staphylococcus aureus } \\
\text { (methicillin susceptible) }\end{array}$ & $11(28.2)$ \\
\hline & $\begin{array}{l}\text { Staphylococcus aureus } \\
\text { (methicillin resistant) }\end{array}$ & $8(20.5)$ \\
\hline & $\begin{array}{l}\text { Coagulase-negative } \\
\text { staphylococci }\end{array}$ & $2(5.1)$ \\
\hline & Pseudomonas aeruginosa & $7(17.9)$ \\
\hline & Streptococcus species & $4(10.3)$ \\
\hline & Serratia marcescens & $3(7.7)$ \\
\hline & Candida species & $4(10.3)$ \\
\hline \multirow[t]{11}{*}{ Polymicrobial } & Total & $36(48.0)$ \\
\hline & $\begin{array}{l}\text { Staphylococcus aureus } \\
\text { (methicillin susceptible) }\end{array}$ & $21(58.3)$ \\
\hline & $\begin{array}{l}\text { Staphylococcus aureus } \\
\text { (methicillin resistant) }\end{array}$ & $12(33.3)$ \\
\hline & Streptococcus species & $7(19.4)$ \\
\hline & Enterococcus species & $8(22.2)$ \\
\hline & Escherichia coli & $13(36.1)$ \\
\hline & Other Enterobacteriaceae & $16(44.4)$ \\
\hline & Pseudomonas aeruginosa & $17(47.2)$ \\
\hline & Stenotrophomonas maltophilia & $2(5.6)$ \\
\hline & Acinetobacter species & $1(2.8)$ \\
\hline & Candida species & $18(50.0)$ \\
\hline
\end{tabular}

\section{Susceptibility Data}

Susceptibility data are shown in Table 6. When combining data from all of the infection sites, 90 of the 215 monomicrobial infections (41.8\%) were caused by MSSA. All these organisms were susceptible to vancomycin. However, 54 of these (60.0\%) had a vancomycin minimal
Table 4 Microbiologic details of surgical site infections following craniotomy

\begin{tabular}{|c|c|c|}
\hline $\begin{array}{l}\text { Types of } \\
\text { infection, } \\
n=45\end{array}$ & Organisms & $N(\%)$ \\
\hline \multirow[t]{5}{*}{ Monomicrobial } & Total & $28(62.2)$ \\
\hline & $\begin{array}{l}\text { Staphylococcus aureus } \\
\text { (methicillin susceptible) }\end{array}$ & $15(53.6)$ \\
\hline & $\begin{array}{l}\text { Staphylococcus aureus } \\
\text { (methicillin resistant) }\end{array}$ & $9(32.1)$ \\
\hline & Pseudomonas aeruginosa & $2(7.1)$ \\
\hline & $\begin{array}{l}\text { Other Gram-negative } \\
\text { bacilli }\end{array}$ & $2(7.1)$ \\
\hline \multirow[t]{9}{*}{ Polymicrobial } & Total & $17(37.8)$ \\
\hline & $\begin{array}{l}\text { Staphylococcus aureus } \\
\text { (methicillin susceptible) }\end{array}$ & $11(64.7)$ \\
\hline & $\begin{array}{l}\text { Staphylococcus aureus } \\
\text { (methicillin resistant) }\end{array}$ & $7(41.2)$ \\
\hline & Pseudomonas aeruginosa & $5(29.4)$ \\
\hline & Enterobacteriaceae & $4(23.5)$ \\
\hline & Streptococcus species & $3(17.6)$ \\
\hline & Bacillus species & $2(11.8)$ \\
\hline & Corynebacterium species & $1(5.9)$ \\
\hline & $\begin{array}{l}\text { Coagulase-negative } \\
\text { staphylococci }\end{array}$ & $1(5.9)$ \\
\hline
\end{tabular}

inhibitory concentration (MIC) $\geq 1.0 \mu \mathrm{g} / \mathrm{ml}$. Sixty $(27.9 \%)$ monomicrobial infections were caused by MRSA, with all isolates being vancomycin susceptible, but with 44 isolates (73.3\%) having a vancomycin MIC $\geq 1.0 \mu \mathrm{g} / \mathrm{ml}$. All staphylococcal isolates were susceptible to linezolid and trimethoprim/sulfamethoxazole, and $>90 \%$ were susceptible to rifampin and minocycline. A limited number of isolates were tested against daptomycin, and all were susceptible. Three of the 16 (18.8\%) $P$. aeruginosa isolates were quinolone resistant, with one being multidrug resistant (i.e., 
Table 5 Microbiologic details of wound infections following abdominal and pelvic surgery

\begin{tabular}{|c|c|c|}
\hline $\begin{array}{l}\text { Types of } \\
\text { infection, } \\
n=89\end{array}$ & Organisms & $N(\%)$ \\
\hline \multirow[t]{8}{*}{ Monomicrobial } & Total & $49(55.1)$ \\
\hline & $\begin{array}{l}\text { Staphylococcus aureus } \\
\text { (methicillin susceptible) }\end{array}$ & $21(42.9)$ \\
\hline & $\begin{array}{l}\text { Staphylococcus aureus } \\
\text { (methicillin resistant) }\end{array}$ & $18(36.7)$ \\
\hline & $\begin{array}{l}\text { Coagulase-negative } \\
\text { staphylococci }\end{array}$ & $1(2.0)$ \\
\hline & Enterococcus species & $1(2.0)$ \\
\hline & Candida species & $1(2.0)$ \\
\hline & Pseudomonas aeruginosa & $5(10.2)$ \\
\hline & $\begin{array}{l}\text { Other Gram-negative } \\
\text { bacilli }\end{array}$ & $2(4.1)$ \\
\hline \multirow[t]{10}{*}{ Polymicrobial } & Total & $40(44.9)$ \\
\hline & $\begin{array}{l}\text { Staphylococcus aureus } \\
\text { (methicillin susceptible) }\end{array}$ & $26(65.0)$ \\
\hline & $\begin{array}{l}\text { Staphylococcus aureus } \\
\text { (methicillin resistant) }\end{array}$ & $19(47.5)$ \\
\hline & Escherichia coli & $19(47.5)$ \\
\hline & Pseudomonas aeruginosa & $9(22.5)$ \\
\hline & Enterococcus species & $9(22.5)$ \\
\hline & Candida species & $9(22.5)$ \\
\hline & Streptococcus species & $9(22.5)$ \\
\hline & $\begin{array}{l}\text { Coagulase-negative } \\
\text { staphylococci }\end{array}$ & $6(15.0)$ \\
\hline & $\begin{array}{l}\text { Other enteric Gram- } \\
\text { negative bacilli }\end{array}$ & $5(12.5)$ \\
\hline
\end{tabular}

resistant to at least three classes of antimicrobial agents expected to be active against it).

As mentioned previously, not all isolates from polymicrobial infections were tested for antimicrobial susceptibility. As with monomicrobial infections, all 73 MSSA isolates were susceptible to vancomycin, but 51 of these
Table 6 Antimicrobial susceptibility of organisms frequently isolated from monomicrobial surgical site infections

\begin{tabular}{|c|c|c|}
\hline Organisms & $\begin{array}{l}\text { Antimicrobial } \\
\text { agent }\end{array}$ & $\begin{array}{l}\% \\
\text { Susceptibility }\end{array}$ \\
\hline \multirow{6}{*}{$\begin{array}{l}\text { Staphylococcus aureus } \\
(90) \text { (methicillin } \\
\text { susceptible) }\end{array}$} & Vancomycin & 100.0 \\
\hline & Linezolid & 100.0 \\
\hline & TMP/SMX & 100.0 \\
\hline & Rifampin & 100.0 \\
\hline & Cefazolin & 100.0 \\
\hline & $\begin{array}{l}\text { Amoxicillin/ } \\
\text { clavulanate }\end{array}$ & 100.0 \\
\hline \multirow{6}{*}{$\begin{array}{l}\text { Staphylococcus aureus } \\
(60) \text { (methicillin } \\
\text { resistant) }\end{array}$} & Vancomycin & 100.0 \\
\hline & Linezolid & 100.0 \\
\hline & TMP/SMX & 100.0 \\
\hline & Rifampin & 100.0 \\
\hline & Cefazolin & 0.0 \\
\hline & $\begin{array}{l}\text { Amoxicillin/ } \\
\text { clavulanate }\end{array}$ & 0.0 \\
\hline \multirow{4}{*}{$\begin{array}{l}\text { Streptococcus species } \\
\quad(21)\end{array}$} & Vancomycin & 100.0 \\
\hline & Linezolid & 100.0 \\
\hline & Cefazolin & 100.0 \\
\hline & $\begin{array}{l}\text { Amoxicillin/ } \\
\text { clavulanate }\end{array}$ & 100.0 \\
\hline \multirow{7}{*}{$\begin{array}{l}\text { Pseudomonas aeruginosa } \\
\text { (19) }\end{array}$} & Amikacin & 89.5 \\
\hline & Cefepime & 84.2 \\
\hline & $\begin{array}{l}\text { Pipercillin/ } \\
\text { tazobactam }\end{array}$ & 89.5 \\
\hline & Meropenem & 89.5 \\
\hline & Ciprofloxacin & 84.2 \\
\hline & Cefazolin & 0.0 \\
\hline & $\begin{array}{l}\text { Amoxicillin/ } \\
\text { clavulanate }\end{array}$ & 0.0 \\
\hline
\end{tabular}

(69.9\%) had a vancomycin MIC $\geq 1.0 \mu \mathrm{g} / \mathrm{ml}$. Of the 50 MRSA strains isolated from polymicrobial infections, 29 (58.0\%) had vancomycin MICs $\geq 1.0 \mu \mathrm{g} / \mathrm{ml}$, although all of 


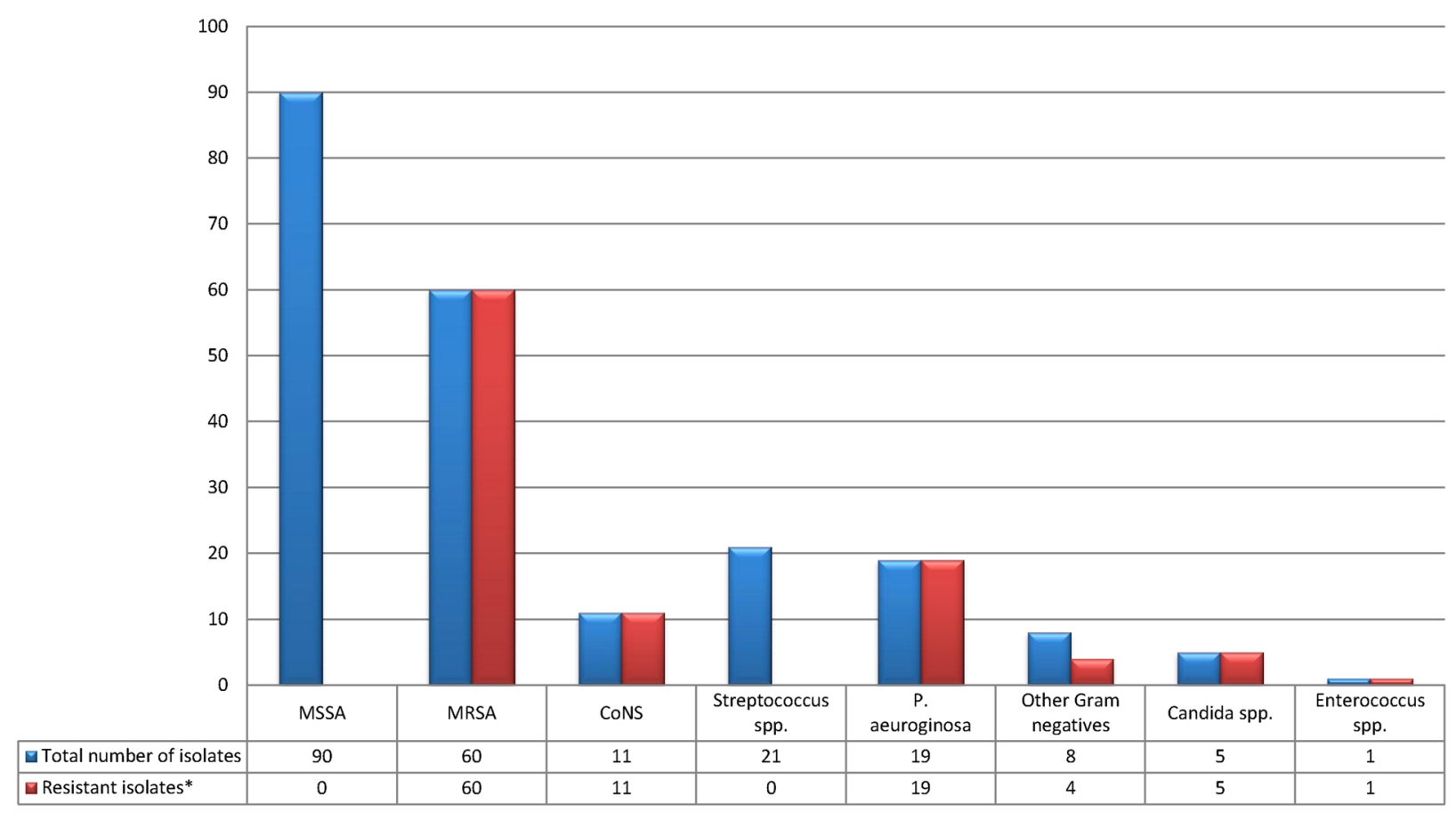

Fig. 1 Details of monomicrobial surgical site infections including the number of isolates resistant to prophylactic agents. MSSA methicillin-susceptible Staphylococcus aureus,
MRSA methicillin-resistant Staphylococcus aureus, CoNS coagulase-negative staphylococci, GNB Gram-negative bacilli these were vancomycin susceptible. All staphylococcal isolates were susceptible to linezolid and trimethoprim/sulfamethoxazole, and $>95.0 \%$ were susceptible to rifampin and minocycline. Of the $39 P$. aeruginosa isolates tested, 7 (17.9\%) were quinolone resistant and 3 $(7.7 \%)$ were multidrug resistant. Among the other Gram-negative bacilli tested, most were relatively susceptible except for Achromobacter spp. and Stenotrophomonas maltophilia, both of which were multidrug resistant. Of the 19 enterococcal isolates tested, $3(15.8 \%)$ were vancomycin resistant, but all were susceptible to daptomycin and linezolid. Overall, $46.5 \%$ of bacterial organisms isolated from monomicrobial SSIs (predominantly MRSA and $P$. aeruginosa) were resistant to amoxicillin/ clavulanate and the first- and secondgeneration cephalosporins (Fig. 1). Although not all organisms isolated from polymicrobial infections were available for susceptibility testing, a similar pattern was noticed among those that were.

\section{DISCUSSION}

SSIs are the most common post-operative complications associated with surgical procedures. They are defined as infections that occur within 30 days of a surgical procedure (or within 1 year, if an implant has been left in place) affecting either the incision or deep tissue at the operative site $[14,15]$. The development of SSIs can lead to prolonged hospital stay with increased costs, medical comorbidity, psychological and emotional trauma, poor cosmetic results, and occasionally, a delay in post-operative adjuvant therapies [16]. Both 
patient-related and procedure-related factors influence the risk of SSIs, and a recent analysis concluded that patient-related factors (e.g., advanced age, diabetes mellitus, and low serum albumin indicative of poor nutritional status, smoking, pre-existing colonization/ infection with $S$. aureus) were predominant [17]. Many of these factors are present in patients with cancer. Additionally, surgical incisions in previously irradiated areas are more likely to have poor or delayed healing, and develop secondary infections. Consequently, infection prevention is important and antimicrobial prophylaxis is recommended for most of these surgical procedures [7-9, 18, 19]. The agents commonly used for prophylaxis (e.g., first- or second-generation cephalosporins; amoxicillin/ clavulanate) were selected several decades ago, based on microbiologic data available then [20]. In the past, methicillin-susceptible $S$. aureus and, to a lesser extent, beta-hemolytic streptococci were the predominant organisms causing SSIs [21]. Data from our study provide confirmation that Gram-positive bacteria remain the most frequently isolated pathogens in SSIs in cancer patients, regardless of the specific site of infection. Of the 157 monomicrobial infections, 129 (82\%) were caused by Gram-positive pathogens. However, streptococci accounted for only $8 \%$ (12 of 157) of these infections, possibly because current prophylactic regimens are still effective against these organisms. In contrast, staphylococci accounted for 109 of 157 episodes of monomicrobial infections (70\%), suggesting that prophylaxis was not particularly effective. Of concern is the fact that $40 \%$ of $S$. aureus isolates were methicillin resistant, and that $67 \%$ of staphylococcal isolates had a vancomycin MIC $\geq 1.0 \mu \mathrm{g} / \mathrm{ml}$. Although there is some variability with susceptibility test results using different methods (E-test, which we used, usually gives higher MIC values than other methods), such organisms have been shown to cause infections that respond slowly, or not at all, to therapy with vancomycin [22-24]. Also of concern is the fact that such isolates are now almost as common among MSSA as they are among MRSA strains. These data have therapeutic implications and suggest that vancomycin might no longer be the agent of choice for the treatment of staphylococcal SSIs at our institution.

We were surprised to find that Gramnegative bacilli caused a substantial proportion (23 of 157 episodes, 15\%) of monomicrobial infections, with $P$. aeruginosa (16 of 23 episodes, $70 \%$ being the predominant pathogen. Although not frequent, the isolation of multidrug-resistant $P$. aeruginosa and other Gram-negative organisms is of some concern. While this epidemiologic shift does not justify the administration of prophylaxis with broadspectrum and/or anti-pseudomonal agents on a routine basis to all patients undergoing surgical procedures (particularly since institutional/ geographic differences do occur), it should not be ignored. Other investigators have also reported an increase in the frequency of SSIs caused by Gram-negative organisms (49\% in one study), and have suggested that alternatives to cefazolin or similar agents, be considered for prophylaxis $[25,26]$. We believe that individual institutions performing substantial numbers of these surgical procedures should generate their own data, and assess their own clinical needs. Since many of these procedures are elective, determining the presence of colonization with problem organisms such as MRSA or $P$. aeruginosa prior to surgery, and administering targeted prophylaxis to patients who are colonized, might be one approach in this setting. Based on our data, and on some 
clinical experience, we have instituted a change in our clinical practice in our breast cancer cohort by providing empiric coverage against Gram-negative organisms including $P$. aeruginosa until microbiologic data become available. We strongly recommend discontinuation of anti-pseudomonal coverage if subsequent cultures do not confirm it as a pathogen.

We were even more surprised to find a high proportion of polymicrobial infections at all surgical sites studied. The combined frequency of polymicrobial infections was $43.3 \%$, ranging from a low of $37.7 \%$ for craniotomy site infections, to a high of $48 \%$ for PEG-tube insertion site infections. We realize that when multiple pathogens are isolated, it is often not possible to determine the exact role played by individual organisms in the pathogenesis of polymicrobial infections. Nevertheless, it is striking that the organisms isolated most frequently from such infections (Staphylococcus species including MRSA and P. aeruginosa) are the same as those isolated most frequently from monomicrobial infections, probably reflecting the inadequacy of the agents used for prophylaxis as well. We have documented an increase in the overall frequency of polymicrobial infections in cancer patients, including patients with and without neutropenia [27]. Based on our current microbiologic data and guidelines provided by our antimicrobial stewardship initiative and on some recent clinical experience, we have instituted changes in our clinical practice by providing broad-spectrum empiric therapy, followed by de-escalation if possible, once microbiologic data become available [28]. We recommend this approach in other institutions that are experiencing epidemiologic changes similar to ours.

\section{CONCLUSION}

Although Gram-positive bacteria continue to be isolated more frequently from SSIs than Gram-negative bacteria, our data from cancer patients indicate that there have been significant changes in the epidemiology of these infections in recent times. The overall frequency of monomicrobial infections has declined, and the incidence of polymicrobial infections has increased considerably. The frequency of streptococci-causing monomicrobial infections has also declined. In contrast, the frequency of MRSA isolation has increased substantially. Additionally, we have noticed an MIC creep with reference to vancomycin, with the majority of current isolates of MSSA and MRSA having vancomycin MICs $\geq 1.0 \mu \mathrm{g} / \mathrm{ml}$. The frequency of Gram-negative bacilli causing monomicrobial SSIs has also increased with $P$. aeruginosa being the predominant pathogen. Staphylococci and $P$. aeruginosa are also the most common pathogens isolated from polymicrobial infections. Approximately, half of the organisms that were available for susceptibility testing were resistant to agents that are commonly used for surgical prophylaxis (cephalosporins, amoxicillin/ clavulanate). These findings have led us to reevaluate our prophylactic and therapeutic options and strategies. We believe that these epidemiologic changes are widespread and encourage other institutions to conduct similar investigations.

\section{ACKNOWLEDGMENTS}

Funding and article processing chargers for this study were funded by University of Texas MD 
Anderson Cancer Center. All named authors meet the ICMJE criteria for authorship for this manuscript, take responsibility for the integrity of the work as a whole, and have given final approval to the version to be published.

Conflict of interest. Kenneth V. I. Rolston, Lior Nesher and Jeffrey T. Tarrand declare no conflict of interest.

Compliance with ethics guidelines. All procedures followed were in accordance with the ethical standards of the responsible committee on human experimentation (institutional and national) and with the Helsinki Declaration of 1975, as revised in 2000 and 2008. Prior to conducting this survey, we obtained approval from our Institutional Review Board.

Open Access. This article is distributed under the terms of the Creative Commons Attribution Noncommercial License which permits any noncommercial use, distribution, and reproduction in any medium, provided the original author(s) and the source are credited.

\section{REFERENCES}

1. Baden LR, Bensinger W, Angarone M, et al. Prevention and treatment of cancer-related infections. J Natl Compr Cancer Netw. 2012;10:1412-45.

2. Safdar A, Armstrong D. Infections in patients with hematologic neoplasms and hematopoietic stem cell transplantation: neutropenia, humoral, and splenic defects. Clin Infect Dis. 2011;53:798-806.

3. Freifeld AG, Bow EJ, Sepkowitz KA, et al. Clinical practice guideline for the use of antimicrobial agents in neutropenic patients with cancer: 2010 update by the Infectious Diseases Society of America. Clin Infect Dis. 2011;52:e56-93.

4. Jacobson K, Rolston K, Elting L, LeBlanc B, Whimbey E, Ho DH. Susceptibility surveillance among Gram-negative bacilli at a cancer center. Chemotherapy. 1999;45:325-34.
5. Rolston KV. Challenges in the treatment of infections caused by gram-positive and gramnegative bacteria in patients with cancer and neutropenia. Clin Infect Dis. 2005;40(Suppl 4):S246-52.

6. Sutton SH. Infections associated with solid malignancies. Cancer Treat Res. 2014;161:371-411.

7. Brahmbhatt RD, Huebner M, Scow JS, et al National practice patterns in preoperative and postoperative antibiotic prophylaxis in breast procedures requiring drains: survey of the American Society of Breast Surgeons. Ann Surg Oncol. 2012;19:3205-11.

8. Lipp A, Lusardi G. Systemic antimicrobial prophylaxis for percutaneous endoscopic gastrostomy. Cochrane Database Syst Rev. 2013;11:CD005571.

9. Mahajan SN, Ariza-Heredia EJ, Rolston KV, et al. Perioperative antimicrobial prophylaxis for intraabdominal surgery in patients with cancer: a retrospective study comparing ertapenem and nonertapenem antibiotics. Ann Surg Oncol. 2014;21:513-9.

10. Walcott BP, Redjal N, Coumans JV. Infection following operations on the central nervous system: deconstructing the myth of the sterile field. Neurosurg Focus. 2012;33:E8.

11. Murray PR BE, Phaller A, Tenover FC, Yolken RH, editors. Manual of clinical microbiology, 9th ed. Washington: ASM; 2007.

12. LaSala PR, Segal J, Han FS, Tarrand JJ, Han XY. First reported infections caused by three newly described genera in the family Xanthomonadaceae. J Clin Microbiol. 2007;45:641-4.

13. CLS M100-S18M-aM-A. Performance standards for antimicrobial susceptibility testing: eighteen informational 305 supplement. Wayne: Clinical and Laboratory Standards Institute; 2008.

14. Horan TC, Gaynes RP, Martone WJ, Jarvis WR, Emori TG. CDC definitions of nosocomial surgical site infections, 1992: a modification of CDC definitions of surgical wound infections. Infect Control Hosp Epidemiol. 1992;13:606-8.

15. Mangram AJ, Horan TC, Pearson ML, Silver LC, Jarvis WR. Guideline for prevention of surgical site infection, Hospital Infection Control Practices Advisory Committee. Infect Control Hosp Epidemiol. 1999;1999(20):250-78.

16. Avritscher EB, Cooksley CD, Rolston $\mathrm{KV}$, et al. Serious postoperative infections following resection of common solid tumors: outcomes, costs, and 
impact of hospital surgical volume. Support Care Cancer. 2014;22:527-35.

17. Dominioni L, Imperatori A, Rotolo N, Rovera F. Risk factors for surgical infections. Surg Infect (Larchmt). 2006;7(Suppl 2):S9-12.

18. Korinek AM, Golmard JL, Elcheick A, et al. Risk factors for neurosurgical site infections after craniotomy: a critical reappraisal of antibiotic prophylaxis on 4,578 patients. Br J Neurosurg. 2005;19:155-62.

19. Sturgis TM, Yancy W, Cole JC, Proctor DD, Minhas BS, Marcuard SP. Antibiotic prophylaxis in percutaneous endoscopic gastrostomy. Am J Gastroenterol. 1996;91:2301-4.

20. Mangram AJ, Horan TC, Pearson ML, Silver LC, Jarvis WR. Guideline for Prevention of Surgical Site Infection, Centers for Disease Control and Prevention (CDC) Hospital Infection Control Practices Advisory Committee. Am J Infect Control. 1999;1999(27):97-132.

21. Pittet B, Montandon D, Pittet D. Infection in breast implants. Lancet Infect Dis. 2005;5:94-106.

22. Sakoulas G, Moise-Broder PA, Schentag J, Forrest A, Moellering RC Jr, Eliopoulos GM. Relationship of MIC and bactericidal activity to efficacy of vancomycin for treatment of methicillin-resistant Staphylococcus aureus bacteremia. J Clin Microbiol. 2004;42:2398-402.
23. Mahajan SN, Shah JN, Hachem R, et al. Characteristics and outcomes of methicillinresistant Staphylococcus aureus bloodstream infections in patients with cancer treated with vancomycin: 9-year experience at a comprehensive cancer center. Oncologist. 2012;17:1329-36.

24. Soriano A, Marco F, Martinez JA, et al. Influence of vancomycin minimum inhibitory concentration on the treatment of methicillin-resistant Staphylococcus aureus bacteremia. Clin Infect Dis. 2008;46:193-200.

25. Mukhtar RA, Throckmorton AD, Alvarado MD, et al. Bacteriologic features of surgical site infections following breast surgery. Am J Surg. 2009;198:529-31.

26. Feldman EM, Kontoyiannis DP, Sharabi SE, Lee E, Kaufman Y, Heller L. Breast implant infections: is cefazolin enough? Plast Reconstr Surg. 2010;126:779-85.

27. Rolston KV, Bodey GP, Safdar A. Polymicrobial infection in patients with cancer: an underappreciated and underreported entity. Clin Infect Dis. 2007;45:228-33.

28. Viola GM, Raad II, Rolston KV. Breast tissue expander-related infections: perioperative antimicrobial regimens. Infect Control Hosp Epidemiol. 2014;35:75-81. 